\title{
Phenotypic and Genotypic Investigation of Yeast Species Associated with Bovine Subclinical Mastitis with a Special Reference to their Virulence Characteristics
}

\author{
Hanaa AE Asfour ${ }^{1}$, Rasha H Eid ${ }^{1}$, Safaa A EL-Wakeel ${ }^{1}$, Tahani S Behour ${ }^{2}$ and Samah F Darwish ${ }^{2 *}$ \\ ${ }^{1}$ Mastitis and Neonatal Diseases Department, Animal Reproduction Research Institute (ARRI), Agricultural Research \\ Center (ARC), Giza, Egypt: ${ }^{2}$ Biotechnology Research Unit, Animal Reproduction Research Institute (ARRI), \\ Agricultural Research Center (ARC), Giza, Egypt \\ *Corresponding author: samahtarek2005@yahoo.com; samah.darwish@arc.sci.eg
}

\begin{tabular}{l} 
Article History: 21-314 Received: 06-May-21 Revised: 18-Jun-21 Accepted: 20-Jun-21 \\
\hline A BSTRA CT \\
This study aimed to investigate yeast species associated with subclinical bovine mastitis in dairy farms. It is based on \\
isolation using Sabouraud dextrose agar (SDA) followed by identification of isolates using HiCrome Candida agar and \\
ITS-PCR-RFLP. Out of 405 milk samples, $31.6 \%$ were positive for yeast isolation on SDA. Based on HiCrome Candida \\
agar and ITS-PCR assay, isolates were classified into 90 pure isolates and 38 mixed cultures. Only pure isolates were \\
subjected to species identification and virulence evaluation. By HiCrome Candida agar media, the most frequently \\
isolated species were $C$. krusei, $C$. tropicalis, and $C$. albicans (13.3\% for each) while $C$. guilliermondii was the least \\
isolated Candida species $(1.5 \%)$. ITS-PCR-RFLP identified 67 isolates which included non-albicans Candida (NAC) \\
species and Trichosporon assahii. Neither $C$. albicans nor $C$. galabrata were identified. Twenty-three isolates could not \\
be identified by ITS-PCR-RFLP. Difference between the results of HiCrome Candida agar and ITS-PCR-RFLP \\
methods was obvious. Considering slime production, $83.6 \%$ were slime producers while $16.4 \%$ were not. All strains of \\
C. krusei, and $C$. tropicalis were slime producers. Regarding biofilm production, $80.6 \%$ of isolates had the ability to \\
form biofilm ranged from strong (6\%), moderate $(14.9 \%)$ to weak (59.7\%) while only 19.4\% were non-biofilm \\
producers. In vitro antifungal susceptibility of isolates displayed different susceptibility and resistance patterns. \\
Conclusively, yeast mastitis in dairy cows demonstrates a growing problem. The diagnosis must rely on accurate \\
laboratory diagnostic tests. The significance of NAC and other yeast genera specifically genus Trichosporon and their \\
role in the etiology of mycotic mastitis should be emphasized.
\end{tabular}

Key words: Yeast, Bovine mastitis, PCR-RFLP, Biofilm formation, Slime production, Antifungal susceptibility.

\section{INTRODUCTION}

Mastitis is the main health problem in bovine dairy herd especially its subclinical form that can cause great harm to dairy herds because of its negative impact on milk production and quality and cow health. Different microorganisms including bacteria and fungi have been implicated as causative agents of bovine mastitis (Krukowski et al. 2006; Khan et al. 2013; Antanaitis et al. 2021). Yeast is the main cause of fungal mammary glands infections and Candida is the most common implicated genus (Dworecka-kaszak et al. 2012). Candida species are considered opportunistic pathogens that colonize the cow udder. Consequently, the abuse of antibacterial agents and contaminated materials brought in contact with the mammary gland, could favor yeast colonization in cow udders (Santos and Marin 2005; Hussain et al. 2013). In
Egypt, there are many predisposing factors that may contribute to the unceasing increase in the prevalence of bovine mycotic mastitis. Among these factors, hot and humid climate, predominant small-scale household rearing systems of cattle, the misuse of excessive antibiotic therapy, and the misdiagnosis and consequent delay of specific antifungal therapy are the most common factors (Abd El-Razik et al. 2011; Juman et al. 2020). In comparison to other mastitis agents, the occurrence of mycotic mastitis was generally very low, but it has been significantly increased during the last years. Candida spp. that isolated in a high percentage from milk may cause either mastitis or systemic candidiasis with probable decline in the strength of immune system of the animal (Krukowski et al. 2001; Qayyum et al. 2016; Sonmez and Erbas 2017).

Conventional identification of yeasts is based on morphological and physiological criteria. These methods

Cite This Article as: Asfour HAE, Eid RH, EL-Wakeel SA, Behour TS and Darwish SF, 2022. Phenotypic and genotypic investigation of yeast species associated with bovine subclinical mastitis with a special reference to their virulence characteristics. International Journal of Veterinary Science 11(1): 49-58. https://doi.org/10.47278/journal.ijvs/2021.071 
are strongly affected by culture conditions giving uncertain results (Kurtzman and Fell 2000). Moreover, phenotypic and biochemical assays are time-consuming and exposed to misdiagnosis, whereas the identification of Candida to species level is essential as many non-albicans Candida developed drug resistance against antifungal agents (Khalaf et al. 2021). Lately, molecular identification using DNA-based tests have begun to be widely used because of their speed, high sensitivity, and specificity. PCR-RFLP analysis is one of the most efficacious methods for yeast identification. It depends on a comparison of the restriction patterns obtained by digestion of a specific target DNA with restriction endonucleases (Fadda et al. 2013; Taei et al. 2019).

Monitoring the virulence of yeast causing mastitis is very imperative. It can provide a new strategy for the prevention and treatment of fungal bovine mastitis. Amongst the virulence determinants, slime production, ability to form biofilm and antimycotic resistance are the most powerful ones. They are mostly associated with the ability to cause persistent infections, therefore; biofilm production could be a possible explanation for bovine mastitis cases that are not resolved by standard treatment strategies (Cengiz et al. 2006; Pedersen et al. 2021). C. albicans in biofilm form is characterized by being resistant to both antifungal drug therapies and host immune defenses (Douglas 2003; Nett and Andes 2006). Many antimycotic drugs have been used for the treatment of yeast mastitis. However, the effectiveness of these drugs was not declared (Zaragoza et al. 2011; Dworecka-Kaszak et al. 2012).

Recently, frequent complaints from the uneffectiveness of the prescribed antibiotic therapy of bovine mastitis cases in several Egyptian dairy farms were received (personal information). Therefore, the present study aimed to investigate yeast species associated with bovine subclinical mastitis based on phenotypic methods of identification. Also, for comparative evaluation, the molecular ITS-PCR-RFLP method was used for accurate and rapid identification of yeast spp. Moreover, virulence factors such as slime production, the capability to form biofilm, and the antifungal susceptibilities of the isolated species were determined.

\section{MATERIALS AND METHODS}

\section{Collection of Milk Samples}

From 405-quarters cow's milk samples were collected from cows suffering from subclinical mastitis (according to California Mastitis Test and somatic cell count (José et al. 2018) with a history of resistance to antibiotic treatment in several dairy farms. Quarter milk samples were collected in sterile vials under aseptic conditions and brought to the laboratory in an ice container for processing as soon as possible. The collection of samples was performed in accordance with rules accepted by the local commission for ethics in animal experimentation and investigation.

\section{Isolation and Identification of Yeasts}

The samples were plated onto the Sabouraud dextrose agar (SDA) [HIGHMEDIUM, India] contained $0.05 \mathrm{mg} / \mathrm{mL}$ Chloramphenicol and incubated at $37^{\circ} \mathrm{C}$ for 48-72h. The cultures were identified at first for morphological characteristics of the grown colonies on
SDA by macroscopical examination. Secondly, the micromorphology of the isolates was examined in wet preparation to detect the formation of chlamydoconidium, germinal tube development in human serum, and pseudohyphae on rice agar medium. Furthermore, microscopical examination of isolates was performed after staining by the Indian ink stain and Gram's stain. HiCrome Candida Differential Agar (HIMEDIUM, India) culture was used for further identification of the isolated species of yeast according to Du et al. (2018).

\section{DNA Extraction}

The method of Zhang et al. (2010) was followed with some modifications. One or two loops of yeast colonies were relocated from chromogenic agar plates into a microcentrifuge tube containing $200 \mu \mathrm{L}$ of pure water. The mixture was mixed and centrifuged at $8000 \mathrm{x}$ g for $1 \mathrm{~min}$ to wash the pellet. After careful removal of the supernatant, $200 \mu \mathrm{L}$ of lysis solution (1\% Triton X100, 0.5\% Tween 20 , $10 \mathrm{mM}$ Tris- $\mathrm{HCl}$ (pH 8.0), and 1mM EDTA, BioBasic, Canada) were added to the resulting pellet, and vortexed well. A boiling step was followed for $10 \mathrm{~min}$. The suspension was centrifuged for $10 \mathrm{~min}$, to sediment the cell debris. The supernatant was collected, transferred to a clean tube and stored at $-20^{\circ} \mathrm{C}$. At the time of PCR, $5 \mu \mathrm{L}$ was used as template DNA.

\section{Molecular Identification using ITS-PCR-RFLP Method}

The internal transcribed spacer (ITS) rDNA region was amplified according to Mirhendi et al. (2006). PCR was carried out in a final volume of $30 \mu 1$. Each reaction included $5 \mu \mathrm{l}$ of template DNA, 30pmol of each primer (ITS1: 5' -TCCGTA GGT GAA CCT GCG G-3', ITS4: 5' -TCC TCCGCT TAT TGA TAT GC-3'), 1x Dream Taq PCR master mix (Thermo Scientific, Lithuania), and nuclease-free water to complete reaction volume. PCR cycling condition was set as follows: initial denaturation at $94^{\circ} \mathrm{C}$ for $5 \mathrm{~min}$, followed by 35 cycles of denaturation at $94^{\circ} \mathrm{C}$ for $30 \mathrm{~s}$, annealing at $58^{\circ} \mathrm{C}$ for $30 \mathrm{~s}$, and polymerization at $72^{\circ} \mathrm{C}$ for $45 \mathrm{~s}$, with final extension step at $72^{\circ} \mathrm{C}$ for $10 \mathrm{~min}$. PCR products were screened using $1.5 \%$ agarose gel electrophoresis at 70 volts until complete separation of bands. The size of amplification products of each isolate was recorded. An aliquot of $10 \mu \mathrm{l}$ of each ITSamplicon was digested according to manufacturing instructions with the restriction enzyme MspI (Thermo Scientific, Lithuania). Patterns of digestion fragments were screened using 3\% agarose gel electrophoresis. Identification of the isolate to the species level was achieved according to both its ITS-amplicon size and its MspI-RFLP pattern as described by Mohammadi et al. (2013).

\section{DNA Sequencing}

Some isolates $(n=8)$ were subjected for sequencing using their ITS-PCR products after being purified using the EZ-10 spin column DNA gel extraction kit (Bio Basic, Canada) according to the manufacturer's recommendations. Eluted DNA was sequenced in an automated ABI 3730 DNA sequencer (Applied Biosystems, USA). ABI sequence files were analyzed using MEGA5 (The Biodesign Institute, Tempe, AZ, USA, 
Tamura et al. 2011) by cutting out $5^{\prime}$ and $3^{\prime}$ regions of high background noise. Consensus sequences were identified using NCBI's Nucleotide BLAST.

\section{Determination of Virulence Determinants Detection of Slime by Congo Red Agar (CRA) Method}

Molecularly identified isolates $(n=67)$ were evaluated for their ability to produce slime by the Congo red agar method (Türky1lmaz and Kaynarca 2010) according to the "Congo red phenomenon". Isolates that produced dark rough red colonies were regarded as slime positive, whereas those appeared as smooth pink or white colonies were considered as slime negative.

\section{Determination of Biofilm Formation}

Molecularly identified isolates were evaluated for biofilm formation using the microtiter plate test according to Dubravka et al. (2010). Each strain was tested 4 times and biofilm production quantities were reported as the arithmetic means of absorbance values of the 4 replicate tests. Cut-off OD (ODc) was defined as three standard deviations above the mean OD of the negative control. Strains were interpreted as follows: non-biofilm producers $(\mathrm{OD} \leq \mathrm{ODc})$; weak biofilm producers $(\mathrm{ODc}<\mathrm{OD} \leq 2 \times$ ODc); moderate biofilm producers $(2 \times$ ODc $<$ OD $\leq 4$ $\times \mathrm{ODc})$ and strong biofilm producers $(4 \times \mathrm{ODc}<\mathrm{OD})$.

\section{Antifungal Susceptibility Testing}

The antifungal susceptibility of 30 representative isolates was determined by the agar disc diffusion method according to the guideline of the Clinical Laboratory Standards Institute for antifungal susceptibility (Fothergill 2012). Eight antimicrobial agents were used including miconazole (MIC; 50 $\mu \mathrm{g} / \mathrm{disk}$ ), ketoconazole (KT; $15 \mu \mathrm{g} /$ disk), amphotericin B (AP; 100units/disk), itraconazole (IT; $10 \mu \mathrm{g} / \mathrm{disk})$, nystatin (NS; 100units/disk), fluconazole (FLC; $25 \mu \mathrm{g} /$ disk), fusidic acid (FC; $10 \mu \mathrm{g} /$ disk) and voriconazole (VRC; $1 \mu \mathrm{g} /$ disk). Results were recorded according to antifungal zone diameters.

\section{RESULTS}

\section{Isolation and Identification}

As summarized in Table 1, 31.6\% out of 405 collected quarter milk samples were positive for primary yeast isolation on SDA. Out of these 128 isolates, 93\% revealed single pure culture while $7 \%$ were mixed yeast cultures. All the yeast isolates were subjected to conventional tests as shown in Fig. 1 (a-f).

\section{Identification using HiCrome Candida Agar-medium}

Identification of the 128 yeast isolates was performed based on HiCrome Candida agar medium. According to culture appearance, $70.3 \%$ of the isolates showed a single colony culture while $29.7 \%$ showed mixed colony cultures. Table 2 summarized the species of isolated yeast, their colony characteristics on HiCrome Candida agar medium, and their prevalence. Fig. 2a to Fig. 2i displayed the characteristic colony morphology of different Candida spp. on HiCrome Candida agar. Mixed Candida spp. infections were also detected as appeared in Fig. 3a to Fig. 3c.

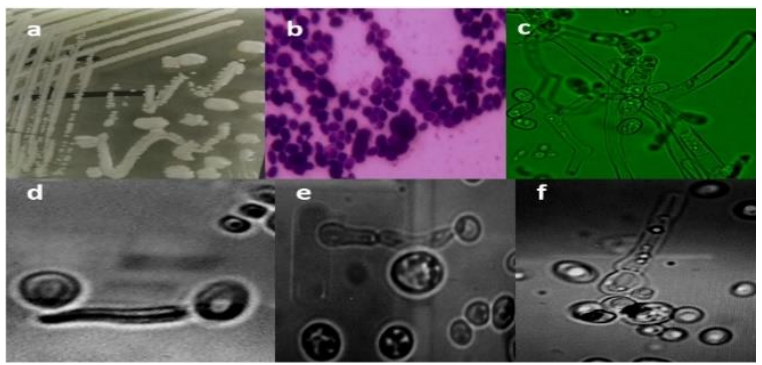

Fig. 1: Characteristic morphology of some yeast spp. a: Growth appearance of yeasts isolated from subclinical mastitis cases on SDA. b: Appearance of Gram-positive staining of the isolated yeast colonies under light microscope X100. c: Wet preparation of $C$. krusei showing the characteristic pseudohyphae with blastoconidia forming cross-matchstick appearance under light microscope 100X. (d, e, f): Wet preparations showed true germ tube formation (d; C. albicans) and early pseudo-hyphal extension with constriction that may be falsely interpreted as germ tubes (e and $\mathrm{f}$; $C$. tropicalis) of different yeasts when grown in human serum under light microscope 100X.

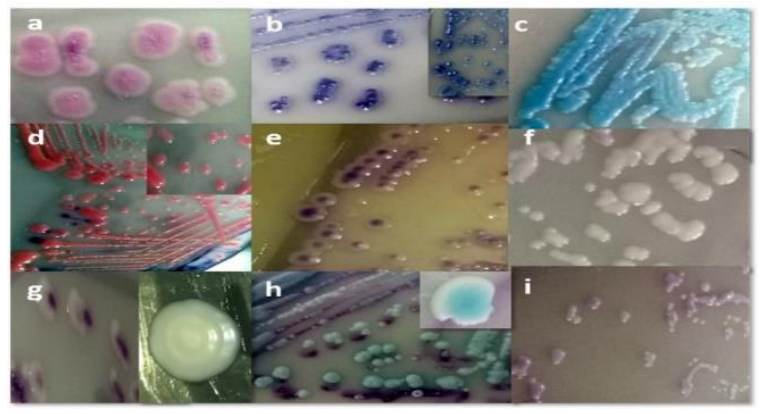

Fig. 2: The characteristic colony morphology of different yeast spp. on HiCrome Candida agar medium. a: pale pink colonies of C. krusei. b: metallic blue colonies of $C$. tropicalis. c: light green colonies of $C$. albicans. d: rose pink colonies of $C$. parapsilosis. e: lilac colonies of $C$. galabrata f: white colonies of $C$. kefyr. g: white to light pink colonies of $C$. famata on HiCrome Candida agar (left) versus its button-like colony on SDA (right). h: greenish pasty colonies of C. rugosa. i: purple colonies of $C$. guilliermondii.

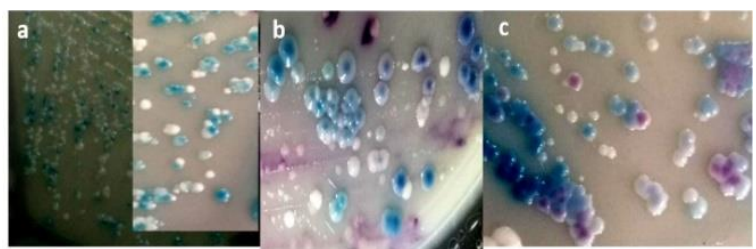

Fig. 3: Mixed infection of different Candida spp. as displayed on HiCrome Candida agar medium a: Mixed infection of C. albicans (green colonies) and C. kefyr (white colonies) b: Mixed infection of $C$. albicans (green colonies) and C. tropicalis (metalic blue colonies). c: Mixed infection of $C$. albicans (green colonies), $C$. galabrata (pink colonies) and C. tropicalis (metalic blue colonies).

Table 1: Percentages of yeasts associated with bovine mastitis and number of pure and mixed culture using different methods.

\begin{tabular}{lcc}
\hline Total No. of samples & 405 \\
\hline No of yeast positive samples (\%) & $128(31.6)$ & \\
\hline Methods & Purity of culture \\
\cline { 2 - 3 } & $\begin{array}{c}\text { Pure culture } \\
\text { No }(\%)\end{array}$ & $\begin{array}{c}\text { Mixed culture } \\
\text { No. }(\%)\end{array}$ \\
\hline SDA & $119(93)$ & $9(7)$ \\
\hline HiCrome Candida agar & $90(70.3)$ & $38(29.7)$ \\
ITS-PCR & $90(70.3)$ & $38(29.7)$ \\
\hline
\end{tabular}


Int J Vet Sci, 2022, 11(1): 49-58.

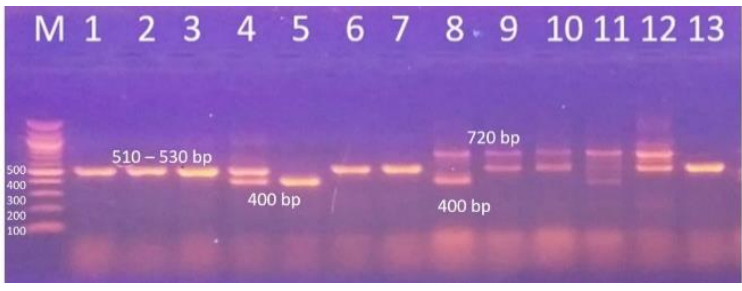

Fig. 4: ITS-PCR products of representative Yeast isolates showing both single and multiple amplicons. M: $100 \mathrm{bp}$ ladder DNA marker, Lanes 1-3, 5-7, 13: single amplicons, Lanes 4, 812: multiple amplicons due to mixed infection.

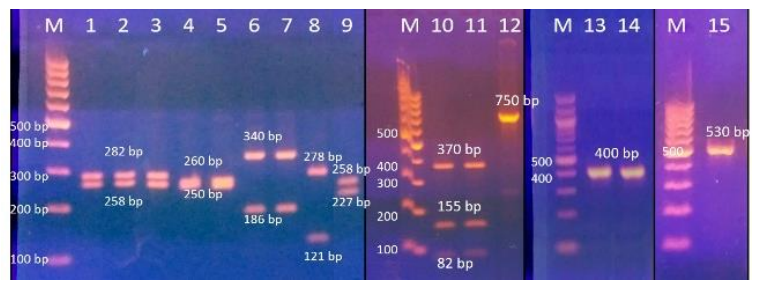

Fig. 5: Agarose gel electrophoresis of ITS-PCR products of different Yeast isolates after digestion with MspI. M: $100 \mathrm{bp}$ ladder DNA marker, 1-3: T. asahii (258\&282 bp), lanes 4-5: $C$. krusei, Lanes 6-7: C. tropicalis, Lane 8: C. rugosa, Lane 9: $C$. norvegenesis, Lanes 10-11: C. guilliermondii, Lane 12: group II (750 bp): not identified, Lanes 13-14: group I (400 bp): not identified, Lane 15: C. parapsillosis complex.

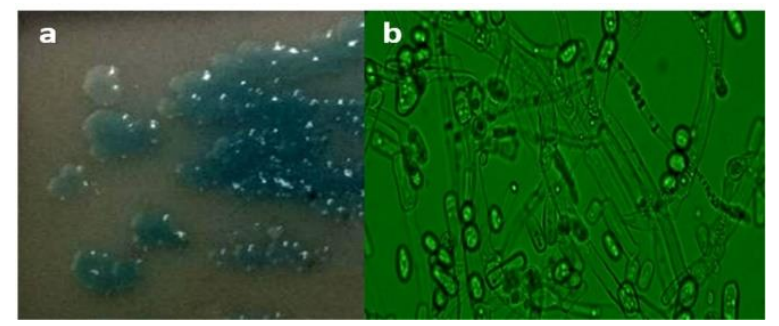

Fig. 6: Characteristic colonies morphology and wet preparation of T. asahii. a: Green Colony appearance of T. asahii that lead to its misidentification as C. albicans on HiCrome Candida agar. b: Wet preparation of $T$. asahii showing the characteristic development of hyaline, septated hyphae that fragment into oval or rectangular arthroconidia (light microscope $100 \mathrm{X}$ ).

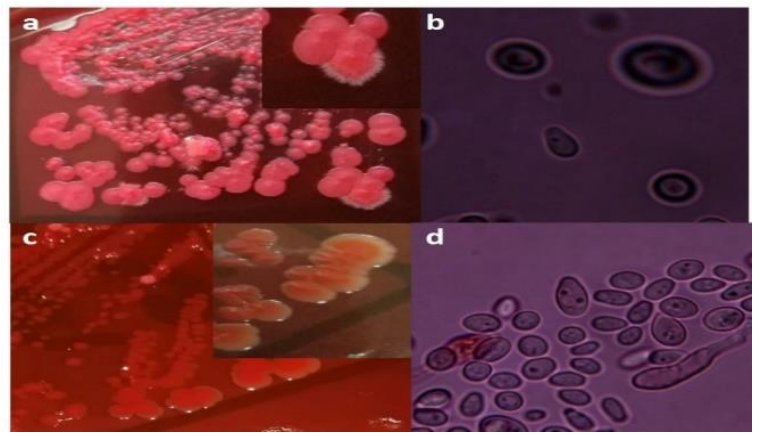

Fig. 7: The characteristics morphology of some yeast spp. on Congo red agar and after staining with Indian ink a: Rough red colonies with filamentous pseudo-hyphal growth of T. asahii (resemble $C$. albicans) on red background of Congo red agar. b: Wet preparation of slime producing Candida spp. stained with Indian ink showed exopolysaccharide layer around the cell wall as examined under light microscope (X100). C: Smooth red colonies of non-slime producer Candida species (C. rugosa) Congo red agar media. d: wet preparation of non-slime producer Candida species stained with Indian ink showed the absence of exopolysaccharide layer around the cell wall examined under light microscope X100.
Table 2: Isolated Yeast species and their colony characteristics on HiCrome Candida agar-medium

\begin{tabular}{|c|c|c|c|}
\hline \multirow{2}{*}{$\begin{array}{l}\text { Species of yeast } \\
\text { Single Candida } \\
\text { infection (No.=90) }\end{array}$} & \multirow[t]{2}{*}{ Colony characteristics } & \multicolumn{2}{|c|}{ No. \%* } \\
\hline & & & \\
\hline C.krusei & $\begin{array}{l}\text { Large, flat, spreading, pale pink } \\
\text { colonies with matt surfaces and the } \\
\text { characteristic fringe. }\end{array}$ & 17 & 13.3 \\
\hline C. tropicalis & Metallic blue colored colonies. & 17 & 13.3 \\
\hline C. albicans & Light green colonies. & 17 & 13.3 \\
\hline C. parapsilosis & Rose pink smooth large colonies. & 13 & 10.2 \\
\hline C. galabrata & Glossy pale pink to lilac colonies. & 9 & 7 \\
\hline C. kefyr & White to light violet colonies. & 7 & 5.5 \\
\hline C. famata & White to light pink colonies. & 4 & 3.1 \\
\hline C. rugosa & to greenish pasty colonies & 4 & 3.1 \\
\hline $\begin{array}{l}\text { C. } \text { guilliermondii } \\
\text { Mixed Candida } \\
\text { infection (No.=38) }\end{array}$ & Small pink to purple colonies. & 2 & 1.5 \\
\hline $\begin{array}{l}\text { C. galabrata+ } \\
\text { C. tropicals. }\end{array}$ & $\begin{array}{l}\text { Lilac and metallic blue colored } \\
\text { colonies }\end{array}$ & 10 & .8 \\
\hline $\begin{array}{l}\text { C. famata+ } \\
\text { C. parapsilosis. }\end{array}$ & Light violet and rosy colonies. & 10 & 7.8 \\
\hline $\begin{array}{l}\text { C. albicans+ } \\
\text { C. kefyr. }\end{array}$ & Green and white colonies. & 8 & 6.3 \\
\hline $\begin{array}{l}\text { C. albicans+ } \\
\text { C. tropicals. }\end{array}$ & etallic blue colonies. & 5 & .9 \\
\hline $\begin{array}{l}\text { C. albicans+ } \\
\text { C. tropicalis+ } \\
\text { C. galabrata. }\end{array}$ & $\begin{array}{l}\text { Green, metallic blue and lilac } \\
\text { colonies. }\end{array}$ & 5 & 3.9 \\
\hline
\end{tabular}

*Percentages were calculated in proportion to total number of isolates (128).

\section{Molecular Identification using ITS-PCR-RFLP}

Based on ITS-PCR results, out of the 128 isolates, 90 produced a single positive PCR product while 38 isolates produced multiple PCR products as displayed in Table 1 and Fig. 4. Only the 90 isolates that produced single band were subjected for species identification by its RFLP. Considering the digestion patterns, 67 out of the 90 pure isolates produced previously reported digestion patterns and therefore were clearly identified to the species level. On the other hand, 23 isolates yielded new digestion pattern and could not be identified to the species level according to previously reported PCR-RFLP results. They were classified according to their amplicon size and digestion products into 2 groups named: I $(n=22 ; 24.4 \%), \Pi(n=1$; $1.1 \%$ ). Table 3 summarized the results of the ITS-PCRRFLP method. It also declared the numbers and percentages of each identified species. Fig. 5 showed the digestion pattern of representative isolates.

\section{Comparison between Identification by using HiCrome Candida Agar Media and ITS-PCR-RFLP Method}

The difference between the identification of yeast isolates on species level between HiCrome Candida agar medium and PCR-RFLP methods was obvious. Out of the 90 studied isolates, the PCR-RFLP results of 47 isolates confirmed their HiCrome results. On the other side, 43 isolates showed deviation between their PCR-RFLP and HiCrome Candida agar results. Table 4 showed the original identification of these 43 isolates by HiCrome Candida agar method versus their molecular identification by ITSPCR-RFLP. Fig. 6a and Fig. 6b showed the characteristic colony morphology of $T$. asahii on the HiCrome agar medium which was very similar to the reported morphology of C. albicans on HiCrome Candida agar. 
Int J Vet Sci, 2022, 11(1): 49-58.

Table 3: Identification of pure yeast isolates using ITS-PCR-RFLP method and their ITS-product size and $M s p I$ digestion patterns.

\begin{tabular}{|c|c|c|c|c|c|c|c|}
\hline $\begin{array}{l}\text { No. of examined } \\
\text { isolates }\end{array}$ & $\begin{array}{l}\text { Obtained digestion } \\
\text { patterns }\end{array}$ & No. & Yeast species & $\begin{array}{l}\text { ITS-PCR product } \\
\text { size }\end{array}$ & $\begin{array}{l}\text { Msp I digestion } \\
\text { fragments }\end{array}$ & No. & $\% *$ \\
\hline \multirow[t]{13}{*}{90} & \multirow{11}{*}{$\begin{array}{l}\text { Previously reported } \\
\text { patterns }\end{array}$} & \multirow[t]{11}{*}{67} & C. krusei & 510 & 250,260 & 16 & 17.8 \\
\hline & & & C. tropicalis & 526 & 186,340 & 9 & 10 \\
\hline & & & C. albicans & - & - & 0 & 0 \\
\hline & & & C. parapsilosis & $510 / 530$ & $510 / 530$ & 13 & 14.4 \\
\hline & & & C. galabrata & 881 & 320,561 & 0 & 0 \\
\hline & & & C. kefyr & 720 & 720 & 8 & 8.9 \\
\hline & & & C. famata & 639 & 639 & 4 & 4.4 \\
\hline & & & C. rugosa & 399 & 121,278 & 8 & 8.9 \\
\hline & & & C. guilliermondii & 607 & $82,155,370$ & 2 & 2.2 \\
\hline & & & C. norvegenesis' & 493 & $8,227,258$ & 1 & 1.1 \\
\hline & & & T. asahii & 540 & 258,282 & 6 & 6.7 \\
\hline & \multirow{2}{*}{ New patterns } & \multirow{2}{*}{23} & Group I Not identified & 400 & 400 & 22 & 24.4 \\
\hline & & & Group II Not identified & 750 & 750 & 1 & 1.1 \\
\hline
\end{tabular}

*Percentages were calculated in proportion to total number of pure isolates (90).

Table 4: Comparison between identification of Yeast species using both HiCrome candida agar and ITS-PCR-RFLP.

\begin{tabular}{|c|c|c|c|}
\hline $\begin{array}{l}\text { Identification by Hi } \\
\text { Crome Candida agar }\end{array}$ & \multirow{2}{*}{$\begin{array}{l}\text { No. } \\
17\end{array}$} & \multicolumn{2}{|c|}{$\begin{array}{l}\text { Identification by ITS-PCR- No. } \\
\text { RFLP }\end{array}$} \\
\hline \multirow[t]{3}{*}{ C. krusei } & & C. Krusei & 13 \\
\hline & & C. norvegenesis & 1 \\
\hline & & Group I (Not identified) & 3 \\
\hline \multirow[t]{4}{*}{ C. tropicalis } & 17 & C. tropicalis & 7 \\
\hline & & C. krusei & 1 \\
\hline & & C. kefyr & 1 \\
\hline & & Group I (Not identified) & 8 \\
\hline \multirow[t]{7}{*}{ C. albicans } & 17 & C. albicans & - \\
\hline & & C. krusei & 1 \\
\hline & & C. tropicalis & 2 \\
\hline & & C. rugosa & 3 \\
\hline & & C. kefyr & 1 \\
\hline & & Group I (Not identified) & 4 \\
\hline & & T. asahii & 6 \\
\hline C. parapsilosis complex & 13 & C. parapsilosis complex & 13 \\
\hline \multirow[t]{2}{*}{ C. galabrata } & 9 & C. rugosa & 3 \\
\hline & & Not identified & 6 \\
\hline \multirow[t]{2}{*}{ C. kefyr } & 7 & C. kefyr & 6 \\
\hline & & Group II (Not identified) & 1 \\
\hline C. famata & 4 & C. famata & 4 \\
\hline \multirow[t]{3}{*}{ C. rugosa } & 4 & C. rugosa & 2 \\
\hline & & C. krusei & 1 \\
\hline & & Group I (Not identified) & 1 \\
\hline C. guilliermondii & 2 & C. guilliermondii & 2 \\
\hline
\end{tabular}

\section{Confirmation of Some Yeast Isolates by Sequencing}

PCR products of the ITS region of some isolates were sequenced and the phylogenetic closest neighbors were determined. It included the 4 isolates that were molecularly identified as T. asahii and the other 4 isolates that couldn't be identified including 3 from group I and 1 of group II. The species of T. asahii was confirmed by blast search and the sequences of 3 of them were successfully submitted to GenBank with accession numbers MT953196, MT953197 and MT953618. Isolates of group I were not similar and submitted to GenBank database as Yarrowia lipolytica, Wickerhaiella pararugosa and Candida catenulate with the following accession numbers: MT953447, MT953577, MT953617, respectively while the isolate of group II was identified as Kluyveromyces lactis withMT966794.

\section{Evaluation of Virulence Determinants \\ Slime Production and Biofilm Forming Ability}

As clarified in Table 5, 83.6\% out of 67 isolates were slime producers (Fig. 7a and 7b) while $16.4 \%$ were nonslime producers (Fig. 7c and 7d). A total of $80.6 \%$ of isolates were able to produce biofilm ranged from strong (6\%), moderate $(14.9 \%)$ to weak $(59.7 \%)$ biofilm producers. Only $19.4 \%$ of the isolates were recorded as non-biofilm producers. Table 5 enumerated the number of biofilm producers amongst each species.

\section{In Vitro Antifungal Susceptibility}

In vitro antifungal susceptibilities of 30 yeast isolates against 8 antifungal agents were presented in Table 6 . It included the susceptibility of randomly selected 6 isolates of each of the subsequent species: $C$. krusei, C. tropicalis, $C$. parapsilosis, $C$. kefyr, and $T$. asahii. Isolates were recorded as either sensitive or resistant to each antifungal agent. None of the examined isolates was found to have an intermediate resistance.

\section{DISCUSSION}

Mastitis is one of the major economic diseases that distressing dairy cattle. In recent years, fungi have been frequently reported as a cause of mastitis (Erbaş et al. 2017; Mohammed and Yassein 2020). Several species of the yeasts of the genera Candida, Cryptococcus, Rhodotorula, and Trichosporon have been associated with mastitis in dairy cows (Akdouche et al. 2018). Candida is generally the most often isolated genus. Variation in both the prevalence and species identified was reported (Krukowski et al. 2006). The present study aimed to rapidly and accurately identify yeast species that might be associated with bovine mastitis. Out of 405 subclinical milk samples, $31.6 \%$ were positive for primary yeast isolation. Different rates of yeast isolation from the milk of cow suffering from mastitis were reported. Lower prevalence $(29.54,29.35,23.44$, and $22.1 \%$ ) of yeast mastitis infections were displayed by Akdouche et al. (2018), Costa et al. (2012), Du et al. (2018), Spanamberg et al. (2008) and Mbuk et al. (2016) in Algeria, Brazil, China, Brazil and Nigeria, respectively. Slightly higher yeasts and yeast-like fungi isolation rates were reported by Khalaf et al. (2021), Asfour et al. (2009), Bekele et al. (2019) and Zhou et al. (2013) with percentages of 47.2, 40.8, 38.18 and $35.6 \%$, in Egypt, Ethiopia and China, respectively. High prevalence was debated by Costa et al. (2012). It has been attributed to insufficient milkers training, repetitive intramammary infusion, and poor teat hygiene prior to the intramammary infusion. Some authors ascribed differences in the distribution of yeast species to both animal species and geographical variations (Seker and Özenç 2011; Gohar et al. 2020). 
Int J Vet Sci, 2022, 11(1): 49-58.

Table 5: Slime production and biofilm forming ability among the identified Yeast species.

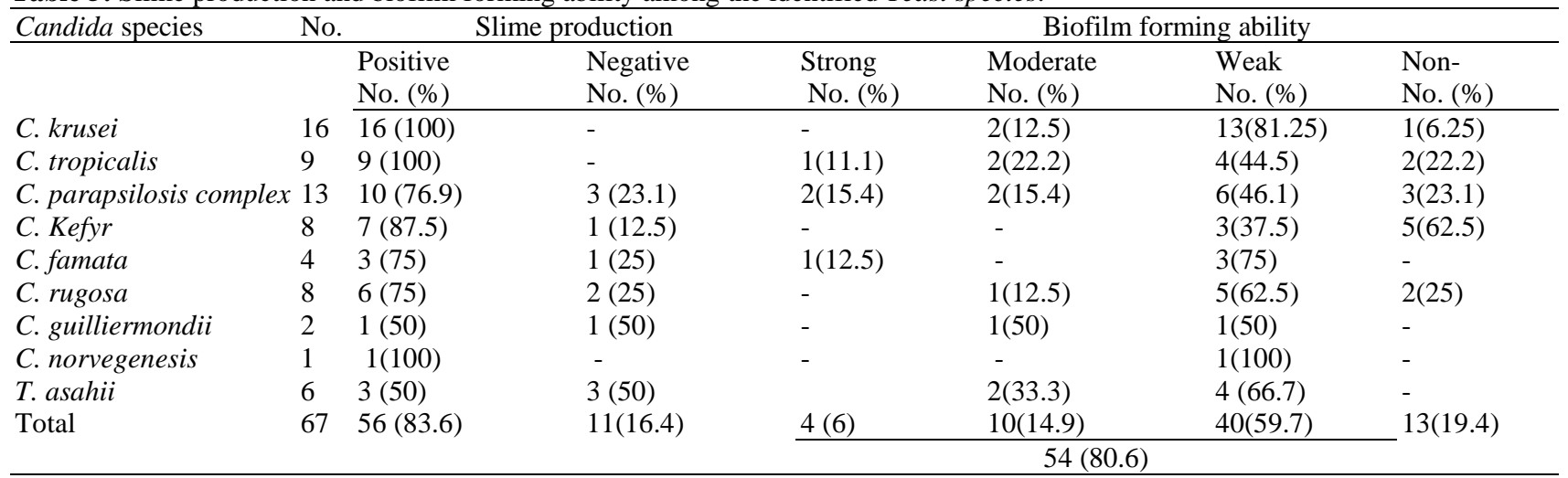

Table 6: Antifungal susceptibilities of representative Yeast species.

\begin{tabular}{|c|c|c|c|c|c|c|c|c|c|c|c|c|c|c|c|c|c|}
\hline \multirow[t]{3}{*}{ Species } & \multirow[t]{3}{*}{ No } & \multicolumn{16}{|c|}{ Antifungal discs* } \\
\hline & & \multicolumn{2}{|c|}{ MIC } & \multicolumn{2}{|c|}{ KT } & \multicolumn{2}{|c|}{$\mathrm{AP}$} & \multicolumn{2}{|c|}{ IT } & \multicolumn{2}{|c|}{ NS } & \multicolumn{2}{|c|}{ FLC } & \multicolumn{2}{|c|}{ FC } & \multicolumn{2}{|c|}{ VRC } \\
\hline & & $S$ & $\mathrm{R}$ & $S$ & $\mathrm{R}$ & $\mathrm{S}$ & $\mathrm{R}$ & $S$ & $\mathrm{R}$ & $\mathrm{S}$ & $\mathrm{R}$ & $S$ & $\mathrm{R}$ & $\mathrm{S}$ & $\mathrm{R}$ & $S$ & $\mathrm{R}$ \\
\hline C. krusei & 6 & 2 & 4 & 6 & - & 6 & - & 6 & - & 6 & - & 6 & - & - & 6 & 6 & - \\
\hline C. tropicalis & 6 & 6 & - & 4 & 2 & 6 & - & 6 & - & 6 & - & 4 & 2 & 2 & 4 & 6 & - \\
\hline C. kefyr & 6 & 6 & & 6 & - & 6 & - & 6 & - & 6 & - & 6 & - & 6 & - & 6 & - \\
\hline C. parapsilosis complex & 6 & 2 & 4 & 4 & 2 & 6 & - & 6 & - & 6 & - & 6 & - & - & 6 & 6 & - \\
\hline T. asahii & 6 & 6 & - & 6 & - & 6 & - & 6 & - & 6 & - & 6 & - & 4 & 2 & 6 & 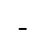 \\
\hline Total No. & 30 & 22 & 8 & 26 & 4 & 30 & - & 30 & - & 30 & - & 28 & 2 & 12 & 18 & 30 & - \\
\hline$\%$ & & 73.3 & 26.7 & 86.7 & 13.3 & 100 & - & 100 & - & 100 & - & 93.3 & 6.7 & 40 & 60 & 100 & . \\
\hline
\end{tabular}

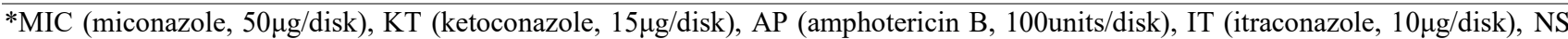
(nystatin, 100units/disk), FLC (fluconazole, $25 \mu \mathrm{g} /$ disk), FC (fusidic acid, $10 \mu \mathrm{g} / \mathrm{disk}$ ) and VRC (voriconazole, $1 \mu \mathrm{g} / \mathrm{disk}$ ).

The traditional methods used for yeasts differentiation in veterinary laboratories are so exhausting and consuming a long time (Imran et al. 2020). So, reducing time is the most important argument required for their identification. Therefore, HiCrome Candida agar was used for faster standing on the species level of yeasts associated with bovine mastitis. Based on the appearance of culture morphology on HiCrome Candida agar media, about $70.3 \%$ was a single yeast infection and $29.7 \%$ was a mixed infection. This was confirmed by further identification by ITS-PCR. Mixed yeast infection of $C$. albicanis and C. krusei in bovine mastitis was also reported (Asfour et al. 2009).

With the developments of molecular biology, many DNA-based techniques have been developed for the identification of yeast species (Mirhendi et al. 2006; Fadda et al. 2013; Mohammadi et al. 2013; Erbas et al. 2017). In our study, a one-enzyme PCR-RFLP assay developed by Mirhendi et al. (2006) was used for identification of yeast isolates. It's based on the use of fungal-specific universal primer pair ITS1 and ITS4 to amplify the internal transcribed spacer region (ITS) of all yeast species followed by restriction fragment length polymorphism for species identification. Molecular identification of yeast isolates revealed that 67 out of the 90 pure isolates produced known reported digestion patterns and therefore were clearly identified to the species level while 23 isolates produced new digestion patterns and so couldn't be identified to the species level.

Because of HiCrome Candida agar medium was not originally developed for the identification of Trichosporon spp. Therefore, some isolates molecularly identified as $T$. asahii were subjected for sequence analysis and BLAST search of the ITS gene sequences. They were confirmed as T. asahii and their sequences were submitted to GenBank with the following accession numbers MT953196, MT953197, and MT953618.Also, representative of isolates displayed new patterns were sequenced. The three isolates representative of the group I, were not similar and were identified as; Yarrowia lipolytica, Wickerhaiella pararugosa, Candida catenulate, and their sequences were uploaded in the GenBank with accession numbers as MT953447, MT953577, MT953617, respectively. Finally, the isolate of the group II was identified as Kluyveromyces lactis with accession number MT966794.

In our study, HiCrome Candida agar enabled the growth of $T$. asahii with colony characteristics resembling those of $C$. albicans. This was observed by PCR-RFLP and confirmed by the sequencing results. Fadda et al. (2013) reported the preliminary identification of the genus Trichosporon, by API to be problematic. On the contrary, they reported that the RFLP technique gave characteristic restriction profiles for each species; moreover, sequencing allowed not only successful identification of certain spp. of Trichosporon where API could not, but also correct identification of misidentified isolates. Nadăş et al. (2014) and Khalaf et al. (2021) held a comparison between phenotypic methods (Chromatic Candida and API 20 CAUX) and a PCR-RFLP analysis for the identification of Candida strains. They found that the Chromatic Candida test is designed for the isolation and identification of some Candida species while other species were difficult to be distinguished by this method; this was attributed to the close similarity of the colonies morphology of some Candida species and therefore, they recommended the genotypic method for the identification of Candida spp. that agreed with our results.

Regarding the comparison between the results of both, HiCrome Candida agar medium and PCR-RFLP methods, the difference was obvious as cleared in Table 4. Out of 90 isolates, 43 showed deviations between their PCR-RFLP results and HiCrome results. These discrepancies may be attributed to the physical individual variation in 
discrimination of colors of the isolated colonies which is the cornerstone of species identification on the HiCrome agar. These differences were reported also by many authors who used different methods for confirmation of yeast species. Jain et al. (2012) recorded that chromogenic agar was certainly the more efficient method over Vitek 2 for identification of the most commonly isolated species but both methods were disabled for identification of some species. Meanwhile, Fadda et al. (2013) mentioned that traditional yeasts identification by morphological and physiological criteria was strongly influenced by culture conditions and hence could give uncertain results. On the contrary, they reported the PCR-RFLP analysis to be one of the most successful methods for yeast identification.

Consequent to the previous findings, we have depended on the accurate results of the PCR-RFLP assay and sequencing technique. It was noticed that non-albicans Candida (NAC) species were the most frequently isolated Candida species among mastitis-causing yeast in this study. Also, other yeast genera such as Trichosporon spp. were involved in bovine mastitis. This was agreed with Zhou et al. (2013), Erbaş et al. (2017) and Akdouche et al. (2018). In the current study, the most identified yeast species were $C$. krusei and $C$. parapsilosis complex (17.8 and $14.4 \%$, respectively) followed by $C$. tropicalis, $C$. kefyr, C. rugosa, and T. asahii (10, 8.9, 8.9, and 6.7\%, respectively). These results resembled that of $\mathrm{Du}$ et al. (2018) and Namvar et al. (2020) who reported that Candida spp. other than $C$. albicans played a pathogenic role in cow's mycotic mastitis. C. krusei was the predominant species isolated and $C$. parapsilosis was the second most frequent Candida in their study. Nearly similar results of C. krusei $(18.18 ; 17.4$ and $19.8 \%$ ) were also reported by Ruz-Peres et al. (2010), Erbas et al. (2017) and Namvar et al. (2020), respectively. Considering $C$. parapsilosis complex, many studies have described their isolation from milk samples with varied frequencies from 0.57 up to $25.4 \%$ and reached to $33.4 \%$ in recent study, depending on the sanitary condition and environmental factors (Zaragoza et al. 2011; Sartori et al. 2014; ErbaŞ et al. 2017; Akdouche et al. 2018; Hussein et al. 2019). In our study, the highest isolation rates of both $C$. krusei and $C$. parapsilosis complex among NAC species could be attributed to the inadequate sanitary practices of milking procedures and the intrinsic natural resistance of $C$. krusei to fluconazole (Freydiere et al. 2001). Moreover, the relative cell-surface hydrophobicity (CSH) of C. parapsilosis adherence to host tissues and plastic surfaces such as milkers or other prosthetic materials is another cause of the high rate of isolation (Panagoda et al. 2001; Kuhn 2002; Trofa et al. 2008). Silage was also reported as a source of lactate assimilating yeasts known to cause mastitis especially $C$. krusei (Elad et al. 1995).

Noteworthy, neither $C$. albicans nor $C$. glabrata were identified among the identified yeast isolates as single yeast infection. Likewise, similar results were also recorded in previous studies (Zaragoza et al. 2011; ErbaŞ et al. 2017; Du et al. 2018; Namvar et al. 2020); they couldn't isolate C. albicans from milk samples collected from cows with subclinical mastitis. This could be explained to some extent to the presence of a greater number of bacteria competing for substrates in subclinical mastitis. Also, some bacterial metabolites are known as yeast antagonists and consequently could restrict some yeast development (Moretti et al. 1998).

Back to our results, C. tropicalis, C. kefyr and $C$. rugosa were also isolated by different rates $(10,8.9$, and $8.9 \%$, respectively) from cow's mastitic milk. Erbaș et al. (2017) isolated the same NAC spp. but with higher frequencies. Also, Hussein et al. (2019) recorded higher rate of $C$. tropicalis isolation (22.7\%) from mastitic cattle. Meanwhile lower isolation rates were obtained by Türkyılmaz and Kaynarca (2010). The lowest yeast species isolations in the current study were $C$. famata, $C$. guilliermondii and $C$. norvegenesis (4.4, 2.2, and $1.1 \%$, respectively). Similar results were identified by Türkyılmaz and Kaynarca (2010) for C. guilliermondii (4.9\%) and C. famata (2.4\%). Recently, Akdouche et al. (2018) reported C. guilliermondii (12.5\%) and C. famata $(1.7 \%)$ in their study.

Considering T. asahii, it was isolated with a percentage of $6.7 \%$. Spanamberg et al. (2008) also identified Trichosporon (4.4\%) from cows suffered from subclinical mastitis. Türkyılmaz and Kaynarca (2010) and Akdouche et al. (2018) identified only 2.4 , and $1.13 \%$, respectively of T. asahii from cows suffered subclinical mastitis. Moreover, Zhou et al. (2013), Bekele et al. (2019) and Lavaee et al. (2020) recorded Trichosporon spp. in percentages of $5.9,3.2$, and $0.8 \%$, respectively from mycotic mastitis in dairy cows. A higher isolation rate of Trichosporon spp. (19.7\%) was reported by Fadda et al. (2013). Spanamberg et al. (2018) reported the presence of Trichosporon spp. in raw milk to be of great concern as their enzymatic activities may alter milk quality and constituents. Also, it creates a hazard where some species of this genus have been reported as both human and animal's pathogens.

Based on the sequencing results and regardless of their isolation rate, Diutina (Candida) catenulate, Wickerhamiella (Candida) pararugosa, Yarrawia (Candida) lipolytica were confirmed by sequencing to be isolated. Similarly, Akdouche et al. (2018) isolated $C$. lipolytica form mastitic cow's milk with a low percentage (1.13\%) while Czernomysy-Furowicz et al. (2008) isolated C. catenulate with a very low percentage $(0.81 \%)$. A higher percentage of Yarrawia lipolytica $(10.9 \%)$ was recorded lately by Bekele et al. (2019) from mastitic dairy cows. Therefore, the involvement of these species in bovine mastitis needs to be more investigated.

Because of the paucity of data concerning the virulence factors of yeast species isolated from bovine milk, investigating the ability to produce slime, form biofilm as well as, antifungal sensitivity of the isolated yeast species was performed in this study. According to our knowledge, this is the first study to investigate these criteria among yeast species isolated from animal sources specifically those associated with bovine mastitis in Egypt.

Regarding slime production, our results revealed that a high percentage (about $83.6 \%$ ) of the identified isolates were slime producers while only $(16.4 \%)$ were not Notably, all strains of $C$. krusei and C. tropicalis were slime producers. Lower percentage was reported by Türkyılmaz and Kaynarca (2010) who found that only $36.6 \%$ of their yeast strains were slime producers. Moreover, they reported that most of non-albicans Candida species were slime producers which settled with our results. Krukowski et al. (2010) demonstrated that $22.34 \%$ of the Candida 
strains were slime producers. Specifically, the majority $(83.33 \%)$ of $C$. krusei were capable of slime formation while other NAC species (C. rugosa and C. guilliermondii) did not form slime.

The ability to form biofilm represents a fundamental role in the pathogenicity of Candida spp. through evading the host immune systems, resisting antifungal therapy, and enduring the competitive pressure from other pathogens (Lahkar et al. 2017). It is considered as a pointer for the development of the infection (Mohammed and Yassein 2020). In this study, about $80.6 \%$ of the examined yeast isolates had the ability to form biofilm ranging from strong $(6 \%)$, moderate $(14.9 \%)$ to weak $(59.7 \%)$ degree, while $19.4 \%$ were non-biofilm producers. Notably, $15.4 \%$ of $C$. parapsilosis complex, $12.5 \%$ of C. rugosa, and $11.1 \%$ of $C$. tropicalis were strong biofilm producers. The most isolated yeast species that showed moderate biofilm production were C. guilliermondii (50\%), T. asahii (33.3\%), C. tropicalis $(22.2 \%)$, C. parapsilosis complex (15.4\%), C. krusei $(12.5 \%)$ and C. rugosa $(12.5 \%)$. More than half of the yeast isolates were weak biofilm producers $(62.2 \%)$. A higher percentage $(94.1 \%)$ of biofilm producers among yeast spp. isolated from animal origins was detected by Cordeiro et al. (2015). In accordance with our results, Brilhante et al. (2014) found that all tested strains of $C$. parapsilosis complex isolated from animals were able to form biofilms and strains from animals produced more biofilm when compared with human isolates. Other studies reported that $C$. tropicalis isolates from animals displayed a greater biofilm formation than $C$. albicans (Chatzimoschou et al. 2011; Estivill et al. 2011). Our result and the limited previous studies on biofilm-forming capability of NAC clearly exposed that these isolates had a high capacity to form biofilms. This could provide resistance to antifungal drugs and could induce mastitis which may be difficult to be treated on the long run. Further, it may represent a potential threat to human and animal health.

Considering the in vitro antifungal susceptibility, a detailed antifungal resistance was investigated. On the level of tested isolates $(n=30)$, the most effective antifungal drugs were AP, IT, NS, and VRC as all isolates were $100 \%$ sensitive to all of them. On the other hand, the least effective anti-mycotic agents were FC, MIC, KT, and FLC because $60,26.7,13.3$, and $6.7 \%$ of the isolates were resistant to them, respectively. The obvious sensitivity of the tested NAC strains may be attributed to the uncommon use of anti-mycotic preparation in the treatment of bovine mastitis in Egypt. This came in agreement with Asfour et al. (2009) who found high sensitivity rates to the used antimycotic drugs in their study. In another study presented by Sonmez and Erbas (2017), they found KT the most effective antifungal agent that can be used for treatment of yeast mastitis and they addressed the development of antifungal resistance in their literature. Natural intrinsic resistances to some antifungals were reported like Gunes et al. (2001) who confirmed natural resistance to fluconazole in both C. krusei and C. glabrata. Our finding supported this literature because $100 \%$ resistance to fluconazole was noticed in both $C$. krusei and C. parapsillosis complex. The differences in the resistance rates between isolates were noticed. Therefore, when yeasts are identified as the cause of mastitis, selection of the appropriate antifungal for treatment is mandatory. Milanov et al. (2014) revealed that the crucial agents in the etiology of bovine mastitis are nonalbicans species of the genus Candida. Tanwani and Yadava (2006) recommended nystatin as intramammary or amphotericin B given intravenously for the treatment of mycotic mastitis. The increase of Imidazole resistance among fungi may be the cause of treatment failure of bovine mycotic mastitis with this preparation (Krukawski and Lisowsko 2007).

\section{Conclusion}

Yeast mastitis in dairy cows demonstrates an increasing problem. Therefore, diagnosis must be relied on accurate laboratory identification of the causative agent. The use of the ITS-PCR-RFLP method was confirmed to provide accurate identification of Candida species. The importance of NAC and their progressed role in the pathogenesis of mycotic mastitis should be highlighted by studying their virulence factors as a routine work in the veterinary laboratories. The involvement of yeast species from genera other than genus Candida in bovine mastitis has to be well investigated.

\section{Financial Acknowledgment}

We gratefully acknowledge Animal Reproduction Research Institute, Agricultural Research Center, Giza, Egypt for its financial support of this work.

\section{Authors' Contributions}

Hanaa AE Asfour and Samah F Darwish designed the research; Hanaa AE Asfour, Rasha $\mathrm{H}$ Eid and Safaa A. Elwakeel performed the experiments of isolation, identification and virulence determination. Samah F Darwish and Tahani S Behour performed the experiments concerning the molecular identification. Hanaa AE Asfour drafted the paper. Samah F Darwish revised, edited and published the manuscript. All the authors revised the manuscript prior to submission for publication.

\section{REFERENCES}

Abd El-Razik K, Abdelrahman K, Abd El-Moez S and Danial E, 2011. New approach in diagnosis and treatment of bovine mycotic mastitis in Egypt. African Journal of Microbiology Research 5: 5725-5732. https://doi.org/10.5897/ajmr11. $\underline{1200}$

Akdouche L, Aissi M and Saadi A, 2018. Prevalence and identification of yeasts responsible for mastitis in dairy cattle farms in the Sidi Lahcene Region in the Wilaya of Sidi Bel abbes- Algeria. Advanced in Dairy Research 6: 206. https://doi.org/10.4172/2329-888x.1000206

Antanaitis R, Juozaitieně V, Jonike V, Baumgartner W and Paulauskas A, 2021. Milk lactoseas a biomarker of subclinical mastitis in dairy cows. Animals 11: 1736. https://doi.org/10.3390/ani11061736

Asfour HAE, El-Metwally AE and Kotb MH, 2009. Yeast as a cause of bovine mastitis and their Histopathological effect on the mammary gland tissues. Journal of Egyptian Veterinary Medicine Association 69: 41-72.

Bekele T, Lakew M, Terefe G, Koran T, Olani A, Yimesgen L, Tamiru M and Demissie T, 2019. Study on bovine mastitis with isolation of bacterial and fungal causal agents and assessing antimicrobial resistance patterns of isolated Staphylococcus species in and around Sebeta Town, 
Ethiopia.African Journal of Microbiology Research 13: 2332. https://doi.org/10.5897/ajmr2018.8909

Brilhante RSN, Rodrigues TJS, Castelo-Branco DSCM, Teixeira CEC, Macedo RB, Bandeira SP, de Alencar LP, Monteiro AJ, Cordeiro RA, Bandeira TJPG, Moreira JLB, Sidrim JJC and Rocha MFG, 2014. Antifungal susceptibility and virulence attributes of animal-derived isolates of Candida parapsilosis complex. Journal of Medical Microbiology 63: 1568-1572. https://doi.org/10.1099/jmm.0.076216-0

Cengiz AS, Us E and Cengiz AT, 2006. The clinical importance of slime production. İnönü Üniversitesi Sanat ve Tasarım Dergisi 13: 193-197.

Chatzimoschou A, Katragkou S and Simitsopoulou M, 2011. Activities of triazole-echinocandin combinations against Candida species in biofilms and as planktonic cells. Antimicrobial Agents and Chemotherapy 55: 1968-1974. https://doi.org/10.1128/aac.00959-10

Cordeiro RA, Oliveira JS, Castelo-Branco DSCM, Teixeira CEC, Marques FJF, Bittencourt PV, Carvalho VL, Bandeira TJPG, Brilhante RSN, Moreira JLB, Pereira-Neto1 WA, Sidrim JJC and Rocha MFG, 2015. Candida tropicalis isolates obtained from veterinary sources show resistance to azoles and produce virulence factors. Medical Mycology 53: 145-152. https://doi.org/10.1093/mmy/myu081

Costa GM, Pereira UP, Souza-Dias MAG and Silva N, 2012. Yeast mastitis outbreak in a Brazilian dairy herd. Brazilian Journal of Veterinary Research and Animal Science 49: 239243. https://doi.org/10.11606/issn.1678-4456.v49i3p239243

Czernomysy-Furowicz D, Karakulska J and Silecka A, 2008. Etiological agents of mastitis in dairy cows on a farm in the west Pomeranian region. Acta Scientiarum Polonorum Zootechnica 7: 3-10.

Douglas LJ, 2003. Candida biofilms and their role in infection. Trends in Microbiology 11: 30-36. https://doi.org/10.1016/ s0966-842x(02)00002-1

Du J, Wang X, Luo H, Wang Y, Liu X and Zhou X, 2018. Epidemiological investigation of non albicans Candida species recovered from mycotic mastitis of cows in Yinchuan, Ningxia of China. BMC Veterinary Research 14: 251. https://doi.org/10.1186/s12917-018-1564-3

Dubravka M, Lazic S, Branka V, Jelena P, Bugarski D and Zorica S, 2010. Slime production and biofilm forming ability by Staphylococcus aureus bovine mastitis isolates. Acta Veterinaria 60: 217-226. https://doi.org/10.2298/avb1003217m

Dworecka-kaszak B, Krutkiewicz A, Szopa D, Kleczkowski M and Biegańska M, 2012. High prevalence of Candida yeast in milk samples from cows suffering from mastitis in Poland. The Scientific World Journal 1: 5. https://doi.org/10.1100/ 2012/196347

Elad D, Shpigel NY, Winkler M, Klinger I, Fuchs, V, Saran A and Faingold D, 1995. Feed contamination with Candida krusei as a probable source of mycotic mastitis in dairy cows. Journal of American Veterinary Medicine Association 207: 620.

Erbaş G, Parin U, Kirkan Ş, Savaşan S, Özavci MV and Yüksel HT, 2017. Identification of Candida strains with nested PCR in bovine mastitis and determination of antifungal susceptibilities. Turkish Journal of Veterinary and Animal Sciences 41: 757-763. https://doi.org/10.3906/vet-1704-39

Estivill D, Arias A, Torres-Lana A, Carrillo-Mùnoz AJ and Arěvallo MP, 2011. Biofilm formation by five species of Candida on three clinical materials. Journal of Microbiological Methods 86: 238-242. https://doi.org/ 10.1016/j.mimet.2011.05.019

Fadda ME, Pisano MB, Scaccabarozzi L, Mossa V, Deplano M, Moroni P, Liciardi M and Cosentino S, 2013. Use of PCRrestriction fragment length polymorphism analysis for identification of yeast species isolated from bovine intramammary infection. Journal of Dairy Science 96: 7692 7697. https://doi.org/10.3168/jds.2013-6996

Fothergill AW, 2012. Antifungal Susceptibility Testing: Clinical Laboratory and Standards Institute (CLSI) Methods Book, 2012.Interactions of Yeasts, Moulds, and Antifungal Agents, pp: 65-74. https://doi.org/10.1007/978-1-59745-134-5_2

Freydiere AM, Guinet R and Boiron P, 2001. Yeast identification in the clinical microbiology laboratory: phenotypical methods. Medical Mycology 39: 9. https://doi.org/10.1080/ $\underline{\text { mmy.39.1.9.33 }}$

Gunes I, Kalkanci A and Kustimur S, 2001. Comparison of three different commercial kits with conventional methods for the identification of Candida strains to species level. Mikrobiyoloji Bulteni 35: 559-64.

Hussain R, Javed MT, Khan A and Muhammad G, 2013. Risks factors associated with sub-clinical mastitis in water buffaloes in Pakistan. Tropical Animal Health and Production 45: 1723-1729. http://dx.doi.org/10.1007/ s11250-013-0421-4

Hussein AM, Salem RM, El-Diasty EM and Marwa AH, 2019. Real time PCR for identification of viable but non culturable fungi isolated from mastitic cattle milk samples depending on propidium mono azide stain. Journal of Current Veterinary Research 2: 112-118.

Imran M, Cao S, Wan SF, Chen Z, Saleemi MK, Wang N, Naseem MN and Munawar J, 2020. Mycotoxins - a global one health concern: A review. Agrobiological Records 2: 1-16. https://doi.org/10.47278/journal.abr/2020.008

Jain N, Mathur P, Misra MC, Behera B, Xess I and Sharma SP, 2012. Rapid identification of yeast isolates from clinical specimens in critically Ill trauma ICU patients. Journal of Laboratory Physicians 4: 30-34. https://doi.org/10.4103/ 0974-2727.98667

Gohar UF, Mukhtar H, Mushtaq A, Farooq A, Saleem F, Hussain MA and Ghani MU, 2020. Fungi: A potential source of biopharmaceuticals. Agrobiological Records 2: 49-62. https://doi.org/10.47278/journal.abr/2020.013

José AF, Thaís CF, Marla S, Lindomar FP, Maiara GB, Marcos BH, Alice MMP, Della L and Fernando NS, 2018 Diagnosing mastitis in early lactation: use of Somaticell ${ }^{\circledR}$, California mastitis test and somatic cell count. Italian Journal of Animal Science 17: 723-729. https://doi.org/10.1080/ 1828051x.2018.1426394

Juman M, Nordin ML, Woldegiorgis EA, Zulkiple SA and Shaari $\mathrm{R}, 2020$. In vitro study of antifungal activity of Averrhoa bilimbi extracts against Candida species. International Journal of Veterinary Science 9: 104-110.

Khalaf DD, Soliman MMH and Mansour AS, 2021. Conventional and molecular identification of mycotic mastitis caused by Candida in farm animals. International Journal of Veterinary Science 10: 64-68. https://doi.org/10.47278/journal.ijvs/ $\underline{2020.011}$

Khan A, Hussain R, Javed MT and Mahmood F, 2013. Molecular analysis of virulent genes (coa and spa) of Staphylococcus aureus involved in natural cases of bovine mastitis. Pakistan Journal of Agricultural Sciences 50: 739-743.

Krukowski H and Lisowski A, 2007. Susceptibility of yeast- like fungi isolated from infected bovine mammary glands to imidazole derivate. Mikologia Lekarska 14: 201-203.

Krukowski H, Lisowski A and Szymankiewicz M, 2010. Intensity of slime production by yeast strains isolated from bovine mastitis cases and their susceptibility to polyenes. Medycyna Weterynaryjna 66: 614-617.

Krukowski H, Lisowski A, Rozanski P and Shorka A, 2006. Yeasts and algae isolated from cows with mastitis in South Eastern part of Poland. Journal of Veterinary Science 9: 181184.

Krukowski H, Tietze M, Majewski T and Różański P, 2001. Survey of yeast mastitis in dairy herds of small-type farms in 
the Lublin region, Poland. Mycopathologia 150: 5-7. https://doi.org/10.1023/a:1011047829414

Kuhn DM, 2002. Comparison of biofilms formed by Candida albicans and Candida parapsilosis on bioprosthetic surfaces. Infection and Immunity 70: 878-88. https://doi.org/10.1128/ iai.70.2.878-888.2002

Kurtzman CP and Fell JW, 2000. The Yeast: A Taxonomic Study. Elsevier, Amsterdam, the Netherlands.

Lahkar V, Saikia L, Patgiri SJ, Nath R and Das PP, 2017. Estimation of biofilm, proteinase and phospholipase production of the Candida species isolated from the oropharyngeal samples in HIV infected patients. Indian Journal of Medical Research 145: 635-640.

Lavaee M, Eidi S and Khoramian B, 2020. High prevalence of Prototheca spp. and isolation of fungal species in milk samples from cows suffering from mastitis in Mashhad city, northeast Iran. Iranian Journal of Veterinary Science and Technology 2: 22-26. https://doi.org/10.22067/veterinary. v11i2.81838

Mbuk EU, Kwaga JKP, Bale JOO and Umoh JU, 2016. Molecular identification of yeasts associated with raw cow milk from peri-urban farms in Kaduna State, Nigeria. Journal of Yeast and Fungal Research 7: 39-46. http://www.academic journals.org/JYFR

Milanov D, Pruniš B, Velhner M and Bojkovski J, 2014. Diagnosis of yeast mastitis in dairy cows. Lucrări Ştiinţifice Medicină Veterinară 47: 56-64.

Mirhendi H, Makimura K, Khoramizadeh M and Yamaguchi H, 2006. A one-enzyme PCR-RFLP assay for identification of six medically important Candida species. Nippon Ishinkin Gakkai Zasshi 47: 225-229. https://doi.org/10.3314/ jimm.47.225

Mohammadi R, Mirhendi H, Rezaei-Matehkolaei H, Ghahri M, Shidfar MR and Jalalizand N, 2013. Molecular identification and distribution profile of Candida species isolated from Iranian patients. Medical Mycology 51: 657-63. https://doi.org/10.3109/13693786.2013.770603

Mohammed SJ and Yassein SN, 2020. Characterization of some virulence factors of Candida albicans isolated from subclinical bovine mastitis. Plant Archives 20: 238-242.

Moretti A, Pasquali P, Mencaroni G, Boncio L and Piergili F, 1998. Relationship between cell counts in bovine milk and the presence of mastitis pathogens (yeasts and bacteria). Journal of Veterinary Medicine, Series B 45: 129-32. https://doi.org/10.1111/j.1439-0450.1998.tb00775.x

Nadăş GC, Kalmár Z, Taulescu MA, Chirilă F, Bouari CM, Răpuntean S, Bolfa P and Fiţ NI, 2014. Comparative identification of Candida species isolated from animals using phenotypic and PCR-RFLP methods. Bulletin of the Veterinary Institute in Pulawy 58: 219-222. https://doi.org/10.2478/bvip-2014-0032

Namvar Z, Sepahy AA, Tabatabaei RR and Rezaie S, 2020. Antifungal susceptibility of non-albicans Candida spp. isolated from raw milk and human blood in Alborz and Tehran provinces. Iranian Journal of Microbiology 11: 520526. https://doi.org/10.18502/ijm.v11i6.2224

Nett J and Andes D, 2006. Candida albicans biofilm development, modeling a host-pathogen interaction. Current Opinion in Microbiology 9: 340-345. https://doi.org/ 10.1016/j.mib.2006.06.007

Panagoda GJ, Ellepola AN and Samaranayake LP, 2001. Adhesion of Candida parapsilosis to epithelial and acrylic surfaces correlates with cell surface hydrophobicity. Mycoses 44: 29-35. https://doi.org/10.1046/j.1439$\underline{0507.2001 .00611 . x}$

Pedersen RR, Krömker V, Bjarnsholt T, Dahl-Pedersen K, Buhl $\mathrm{R}$ and Jørgensen E, 2021. Biofilm research in bovine mastitis. Frontiers in Veterinary Science 8: 1-11. https://doi.org/10.3389/fvets.2021.6568108:1-11
Qayyum A, Khan JA, Hussain R, Avais M, Ahmed N, Khan A and Khan MS, 2016. Prevalence and association of possible risk factors with sub-clinical mastitis in Cholistani cattle. Pakistan Journal of Zoology 48: 519-525.

Ruz-Peres M, Benites NR, Yokoya E and Melville PA, 2010. Resistência de fungos filamentosos e leveduras isolados de leite CRU bovino à pasteurização e fervura. Veterinária e Zootecnia 17: 62-70.

Santos RC and Marin JM, 2005. Isolation of Candida species from Mastitic bovine milk in Brazil. Mycopatholia 159: 251253. https://doi.org/10.1007/s11046-004-2229-2

Sartori LCA, Santos RC and Marin JM, 2014. Identification of Candida species isolated from cows suffering mastitis in four Brazilian states. Arquivo Brasileiro de Medicina Veterinária e Zootecnia. 66: 1615-1617. https://doi.org/10.1590/1678-7576

Seker E and Özenç E, 2011. In vitro biofilm activity of Candida species isolated from Anatolian buffaloes with mastitis in Western Turkey. Veterinarski Arhiv 81: 723-730.

Spanamberg A, Hartfelder C, Fuentefria AM and Valente P, 2018. Diversity and enzyme production by yeasts isolated from raw milk in Southern Brazil. Acta Scientiae Veterinariae 32: 195-199. https://doi.org/10.22456/1679-9216.16897

Spanamberg A, Jr Wünder EA, Brayer Pereira DI, Argenta J, Cavallini Sanches EM, Valente P and Ferreiro L, 2008 Diversity of yeasts from bovine mastitis in Southern Brazil. Revista Iberoamericana de Micología 25: 154-156. https://doi.org/10.1016/s1130-1406(08)70036-6

Sonmez M and Erbas G, 2017. Isolation and identification of Candida spp. from mastitis cattle milk and determination of antifungal susceptibilities. International Journal of Veterinary Science 6: 104-107.

Taei M, Chadeganipour M and Mohammadi R, 2019. An alarming rise of non-albicans Candida species and uncommon yeasts in the clinical samples; a combination of various molecular techniques for identification of etiologic agents. BMC Research Notes 12: 779. https://doi.org/ 10.1186/s13104-019-4811-1

Tamura K, Peterson D, Peterson N, Stecher G, Nei M and Kumar S, 2011. MEGA5: Molecular evolutionary genetics analysis using maximum likelihood, evolutionary distance, and maximum Parsimony methods. Molecular Biology and Evolution 28: 2731-2739. https://doi.org/10.1093/molbev/ $\underline{\operatorname{msr} 121}$

Tanwani SK and Yadava R, 2006. Fungi responsible formastitis in animals. Agricultural Entomology. Public Health, April.

Trofa D, Gacser A and Nosanchuk JD, 2008. Candida parapsilosis, an emerging fungal pathogen. Clinical Microbiology Reviews 21: 606-625. https://doi.org/ 10.1128/cmr.00013-08

Türky1lmaz S and Kaynarca S, 2010. The slime production by yeast isolated from subclinical mastitic cows. Acta Veterinaria Brno 79: 581-586. https://doi.org/10.2754/avb 201079040581

Zaragoza CS, Olivares RAC, Watty AED, Moctezuma AP and Tanaca LV, 2011. Yeasts isolation from bovine mammary glands under different mastitis status in the Mexican High Plateu. Revista Iberoamericana de Micología 28: 79-82. https://doi.org/10.1016/i.riam.2011.01.002

Zhang YJ, Zhang S, Liu XZ, Wen HA and Wang M, 2010. A simple method of genomic DNA extraction suitable for analysis of bulk fungal strains. Letters in Applied Microbiology 51: 114-118. https://doi.org/10.1111/j.1472765x.2010.02867.x

Zhou Y, Ren Y, Fan C, Shao H, Zhang Z, Mao W, Wei C, Ni H, Zhu Z, Hou X, Piao F and Cui Y, 2013. Survey of mycotic mastitis in dairy cows from Heilongjiang Province, China Tropical Animal Health and Production 45: 1709-1714. https://doi.org/10.1007/s11250-013-0419-y 